\title{
FUNCTIONAL SENTENCE PERSPECTIVE
}

\section{CA. R. Ryukova}

Bashkir State University

32 Zaki Validi Street, 450076 Ufa Republic of Bashkortostan, Russia.

\author{
Phone: +7 (347) 2515907.
}

Email: aisylu-r@mail.ru

\begin{abstract}
The article deals with the question of actual division of the sentence, which is also referred to as the functional sentence perspective. At different times, the given problem was considered by various scholars, such as F. Danes,, V. Mathesius, Yu. S. Maslov, G. A. Zolotova, and others. The actual division of the sentence should be opposed to the formal grammatical sentence segmentation. Any utterance presents the course of thought from the known, which is articulated by the speaker, to what is not yet known to the listener. Forming a message, the speaker is sure to take into account the listener's knowledge about the subject of the utterance. The most important means of actual sentence division are word order and intonation. The theme of the utterance is identical to the subject of the sentence. The rheme coincides with the predicate of the proposition and is grammatically transferred as the predicate of the sentence. However, there are certain differences between the categories of logic and the categories of communication. Due to that fact, the discrepancies between the predicate as the ascertaining element of a proposition and the rheme as a communicative category are observed.
\end{abstract}

Keywords: actual sentence division, subject, predicate, utterance, theme, rheme, thematic fronting.

Communicative syntax is a field of linguistic research the subject of which is the organization of an utterance by a subject in the process of communication according to their intention. Some linguists believe that it would be more correct to refer to this trend as 'actual syntax' after the founders of the theory of actual sentence division [9].

According to V. Mathesius the actual division of the sentence should be opposed to its formal division. The formal segmenting of a sentence divides the structure of the sentence into its grammatical components, while the actual division shows how the sentence is included in the subject context. Thus, the grammatical subject and grammatical predicate are the principal components of the formal sentence segmenting, while the main elements of the actual division are the starting point (the basis) of the utterance, that is, what is known and easily understood in this situation, and the core of the utterance, that is, what the speaker says about the starting point of the utterance [7, p. 239].

H. Paul also turned to similar problems developing ideas about the 'psychological subject' and 'psychological predicate'. H. Paul considered the 'psychological predicate' to be the most important as it is strongly emphasized. [8, p. 339]. V.B. Kasevich states that the theme-rhematic segmentation of a statement goes back to Aristotle's two-component 'subjectpredicate' proposition [5, pp. 244-245]. Representatives of the Prague linguistic circle V. Mathesius and F. Daneŝ deserve credit for developing the idea of the communicative perspective and actual division in analyzing the sentence and the text. The theories of these two linguists are interconnected; the thematic progression of F. Daneŝ is a logical continuation of the idea of distinguishing the rheme and theme.

The categories of actual division of the sentence are connected with the construction of the text as they take into account the communicative perspective of the sentence within the framework of the expanding utterance. The author of the message cannot transfer all information at once. The linearity of speech determines a certain order of the message elements. Taking into account the fact that various elements of the utterance are not equal in their communicative significance, the choice of the order they follow in the message plays an important role in the communication process.

Any utterance presents the course of thought from the known, which is articulated by the speaker, to what is not yet known to the listener. Forming a message, the speaker is sure to take into account the listener's knowledge about the subject of the utterance. Due to this knowledge, the speaker makes the known part of the message its starting point and tells the listener something new in the other part. Such a division of the statement into the theme and rheme reproduces the current position of the speaker in each particular case in relation to the content of the statement and to the listener. The division of statements into the theme and rheme depends on particular situation and context. As it was claimed by Yu. S. Maslov, "actual information is that angle of view under which material information is supplied, something without which material information loses its purposefulness" [6, pp. 182-183].

Word order and intonation are the most important means of actual sentence division. The theme usually precedes the rheme. Apart from intonation and word order, there are other means of transferring relevant information: articles, voice transformations, intensifying particles. The theme of the statement also has special markers. Thus, V. B. Kasevich identifies the following methods for marking the theme: positional (the theme is located in the initial position); grammatical, which involves the use of special forms, syntactic constructions or functional words; lexical, which involves the use of special lexical constructions; phonetic (pauses and speech melody) [5, p. 258]. 
Considering various types of actual sentence division, G. A. Zolotova describes the relationships between the theme and the rheme that emerge due to parallel and sequential development of inter phrase connections in the text $[4$, p. 388]. The author makes the following conclusions: the rheme in a sentence is an interacting link where vocabulary and grammar are interconnected. The rheme inside the utterance, opposed to the theme, connects the initial and new information which is communicatively significant. Outside the sentence the rheme enters into semantic, notional relationships with the rhemes of other neighboring sentences and they create the rhematic dominant of a text fragment which is characterized by semantic identity and results in the text segmentation.

N. D. Arutyunova analyzes the concept of the theme and the rheme in direct connection with the concepts of grammatical subject and predicate, which are opposed to each other as the subject of the message and what is being informed. In the classic case, one may notice a combination of all three plans. The theme of the utterance is identical to the subject of the proposition and is defined as the subject in the sentence. The rheme coincides with the predicate of the proposition and is grammatically transferred as the predicate of the sentence. However, such a coincidence is often broken due to discrepancies between the categories of logic and the categories of communication. The author shows the quantitative and qualitative differences between the predicate as the ascertaining element of a proposition, and the rheme as a communicative category [3].

The position of the grammatical predicate has limitations of a quantitative character. The predicate must be semantically complete; an incomplete word cannot be a predicate. Its size is determined by the semantic criterion, not the formal one. Therefore, linguists in determining the category of the predicate rely on the concept of logical proposition the full value of which is achieved with the full value of its predicate.

The predicate should be characterized by a certain semantic autonomy. On the other hand, the rheme is determined by any amount of meaning, no matter how small it may be. There lies the quantitative difference between the core of the utterance, the rheme, and the proposition core, the predicate. The qualitative difference between the predicate and the rheme is as follows:

1. The predicate indicates properties, attributes, actions, states of the subject. The predicate has a characterizing value. In syntax there was formed the category of attributive words, verbs and adjectives.

2. The communication requirements are wider. The purpose of the message may be an indication of specific objects and their names. The position of the rheme can be occupied not only by a word of the attributive value, but also by the subjective one, including the cases when there is a reference to a specific subject, for example, a proper name.

In terms of informative value, the rheme is more important for an utterance than the theme since new information is connected with it. However, in the internal structure of the text, the role of the theme increases. The thematic structure of the text is characterized by a peculiar linking of themes, their connection with separate parts of the text and with the text as a whole. F. Danes identifies the whole complex of thematic relations in the text as 'thematic progression' and singles out five basic types of thematic progression in the text. Thematic progressions are abstract models used in constructing a text [1, p. 185].

The first type is a simple linear progression or a progression with linear thematic fronting. This type is characterized by successive expansion of information where the rheme of the previous sentence is transferred to the theme of the next sentence.

The second type is a progression with a crosscutting theme. The peculiarity of this progression is one theme that is repeated in each utterance.

The third type is a progression with derived themes. This progression covers such cases of thematic organization of the text when each sentence serves to express a general thematic focus. The main topic can be explicitly expressed by the speaker or formulated on the basis of particular descriptions.

The next type is a progression with a split theme. The basis of this progression is a double rheme the components of which under thematic fronting form the starting points for the expansion of independent thematic progressions. Separate independent thematic progressions can develop alternately.

The fifth type is a progression with a thematic leap. This type of progression involves a gap in the thematic-rhematic chain, easily reconstructed from the context.

In fact, one can observe a complex interaction of various thematic lines that represent speaker's communicative strategy that he uses to transfer the communicative concept.

\section{References}

1. Danê̂ F. Textlinguistik. Hrsg. Von W. Dressler. Darmstadt, 1978.

2. Mathesius V. A Functional Analysis of Present day English on a General Linguistic basis. The Hague: Mouton, 1975.

3. Arutyunova N. D. Yazyk i mir cheloveka [Language and the world of human]. Moscow: Yazyki russkoi kul'tury, 1999. I-XV.

4. Zolotova G. A., Onipenko N. K., Sidorova M. Yu. Kommunikativnaya grammatika russkogo yazyka [Communicative grammar of the Russian language]. Moscow, 1998.

5. Kasevich V. B. Buddizm. Kartina mira. Yazyk [Buddhism. Picture of the world. Language]. Saint Petersburg, 1996.

6. Maslov Yu. S. Vvedenie v yazykoznanie: 2 ed. [Introduction to linguistics: 2nd ed.]. Moscow, 1987.

7. Matezius V. Prazhskii lingvisticheskii kruzhok. Moscow, 1967.

8. Paul H. Printsipy istorii yazyka [Principles of the history of language]. Moscow, 1960.

9. Slyusareva N. A. Voprosy yazykoznaniya. 1986. No. 4 


\section{ФУНКЦИОНАЛЬНАЯ ПЕРСПЕКТИВА ПРЕДЛОЖЕНИЯ}

\section{(C) А. Р. Рюкова}

Башкирский государственный университет

Россия, Республика Башкортостан, 450076 г. Уфа, ул. Заки Валиди, 32.

Тел.: +7 (347) 2515907.

Email:aisylu-r@mail.ru

В статье рассматриваются проблемы функциональной перспективы предложения. Вопрос об актуальном членении высказывания интересовал многих ученых, таких как В. Матезиус, Ф. Данеш, отечественных лингвистов: Н. Д. Арутюнову, В. Б. Касевича, Ю. С. Маслова, Г. А. Золотову, и др. Актуальное членение предложения необходимо противопоставлять формальному грамматическому членению предложения. Любое высказывание представляет собой ход мысли от известной информации, передаваемой говорящим, к неизвестной для слушателя. При формировании высказывания говорящий обязательно принимает во внимание знания слушающего по высказываемой теме. Наиболее важными способами актуального членения высказывания являются порядок слов и интонация. Тема высказывания совпадает с синтаксическим субъектом предложения, а рема - с предикатом суждения и формальным сказуемым в предложении. Однако такое совпадение часто нарушено из-за расхождения между категориями логики и категориями коммуникации. Наблюдаются количественные и качественные различия между предикатом, как констатирующим элементом суждения, и ремой, как коммуникативной категорией.

Ключевые слова: актуальное членение предложения, субъект, предикат, высказывание, тема, рема, тематизация.

\section{ЛИТЕРАТУРА}

1. Danê̂ F. Zur linguistischen Analyse der Textstruktur // Textlinguistik / Hrsg. Von W. Dressler. Darmstadt, 1978.

2. Mathesius V. A Functional Analysis of Present day English on a General Linguistic basis. The Hague: Mouton, 1975.

3. Арутюнова Н. Д. Язык и мир человека. М.: Языки русской культуры, 1999. I-XV. 896 с.

4. Золотова Г. А., Онипенко Н. К., Сидорова М. Ю. Коммуникативная грамматика русского языка. М., 1998.528 с.

5. Касевич В. Б. Буддизм. Картина мира. Язык. СПб., 1996.

6. Маслов Ю. С. Введение в языкознание: 2-е изд. М., 1987.

7. Матезиус В. О так называемом актуальном членении предложения // Пражский лингвистический кружок. М., 1967.

8. Пауль Г. Принципы истории языка. М., 1960.

9. Слюсарева Н. А. Категориальная основа тема-рематической организации высказывания-предложения // Вопросы языкознания. 1986. №4. 